\title{
Mastigotragus, a new generic name for Mastigoteuthis pyrodes Young, 1972 (Cephalopoda: Mastigoteuthidae)
}

\author{
Richard E. YOUNG,${ }^{1}$ Michael VECCHIONE ${ }^{2}$ \& Heather E. BRAID ${ }^{3}$ \\ ${ }^{1}$ University of Hawaii, Honolulu, Hawaii, USA. Email: dickphyllisyoung@gmail.com \\ ${ }^{2}$ NMFS National Systematics Laboratory, Smithsonian Institution, Washington, DC, USA. \\ Email: vecchiom@si.edu \\ ${ }^{3}$ Institute for Applied Ecology New Zealand, Auckland University of Technology, Auckland, \\ New Zealand. Email: heather.braid@gmail.com \\ ${ }^{1}$ urn:1sid:zoobank.org:author:C5177553-E350-4C6A-9D2E-70581F2ED152 \\ ${ }^{2}$ urn:Isid:zoobank.org:author:E79EA1DA-A7B4-482D-A5E3-AB81E74E4743 \\ ${ }^{3}$ urn:lsid:zoobank.org:author:A28B5D88-B00C-46A1-9F48-367918CAF2F2
}

\begin{abstract}
A recent paper on the phylogenetic relationships of species within the cephalopod family Mastigoteuthidae meant great progress in stabilizing the classification of the family. The authors, however, left the generic placement of Mastigoteuthis pyrodes unresolved. This problem is corrected here by placing this species in a new monotypic genus, Mastigotragus, based on unique structures of the photophores and the funnel/mantle locking apparatus.
\end{abstract}

Keywords. Mastigoteuthidae, morphology, nomenclature, Mastigotragus gen. nov., deep-sea squid

Young R.E., Vecchione M. \& Braid H.E. 2014. Mastigotragus, a new generic name for Mastigoteuthis pyrodes Young, 1972 (Cephalopoda: Mastigoteuthidae). European Journal of Taxonomy 105: 1-6. http://dx.doi. org/10.5852/ejt.2014.105

\section{Introduction}

The squid family Mastigoteuthidae contains oceanic, mostly bathypelagic, species that are soft bodied and easily damaged in trawls. The inaccessibility of species and their fragile nature are in large degree responsible for problems in the classification of this family. Little consistency has existed between classifications, even with the same senior author (e.g., Salcedo-Vargas \& Okutani 1994 and SalcedoVargas 1997). In a revision of the family on the Tree of Life website, Vecchione et al. (2004, with subsequent modifications up to 2014) suggested, because of the uncertainties in classification, "... that modifying the classification is premature and should wait until our knowledge has increased to the point where a full phylogenetic study can be made. We recognize, therefore, only the single genus Mastigoteuthis." Vecchione et al. (2004-2014) then placed species (excluding species of doubtful validity and those known only from paralarvae; see below) into the following six species groups: Mastigoteuthis agassizii group (three-species group), M. cordiformis (one-species group), M. glaukopis group (threespecies group), M. hjorti (one-species group), M. magna group (two-species group) and M. pyrodes (one-species group). The excluded species from the Vecchione et al. species groups are: Mastigoteuthis 
latipinna (Sasaki, 1916), M. islini MacDonald \& Clench, 1934, M. inermis Rancurel, 1972, M. okutani (Salcedo-Vargas, 1997) and Chiroteuthoides hastula Berry, 1920.

The phylogenetic study that was called for by Vecchione et al. (2004-2014) to establish a proper classification for the Mastigoteuthidae has now been published by Braid et al. (2014). Those authors analyzed three mitochondrial genes from 29 mastigoteuthid squids in eight species and re-examined morphological characters. Their results agreed with the species groups established by Vecchione et al. (2004-2014) and enabled them to establish a formal generic classification for the family that utilized generic and subgeneric names previously present in the literature. The following table compares these two classification systems:

\section{Comparison of classifications}

\begin{tabular}{lll} 
& Vecchione et al. 2004-2014 & Braid et al. 2014 \\
\hline 1 & The Mastigoteuthis agassizii group & Mastigoteuthis spp. \\
2 & Mastigoteuthis cordiformis & Idioteuthis cordiformis \\
3 & The Mastigoteuthis glaukopis group & Echinoteuthis spp. \\
4 & Mastigoteuthis hjorti & Mastigopsis hjorti \\
5 & The Mastigoteuthis magna group & Magnoteuthis spp. \\
6 & Mastigoteuthis pyrodes & Mastigoteuthis pyrodes (no change) \\
\hline
\end{tabular}

Braid et al. (2014) left one problem unresolved. They stated, "Unfortunately, no specimens of this species [Mastigoteuthis pyrodes] were examined or available for genetic analysis, and therefore, its generic placement remains unclear." In this paper we examine the generic affinities of Mastigoteuthis pyrodes Young, 1972 and place it in a new genus.

\section{Materials and methods}

We examined all of the specimens of Mastigoteuthis pyrodes at the U.S. National Museum of Natural History (USNM) and at the Santa Barbara Museum of Natural History (SBMNH). Included were the following type specimens: SBMNH 34983, holotype, ${ }^{\lambda}$, ML $110 \mathrm{~mm}$, and USNM 727462, 3 paratypes ( 2 ふैं , ML 85 and $94 \mathrm{~mm}$; 1 sex indet., ML $77 \mathrm{~mm}$ ).

\section{Results}

We strongly support most of the conclusions reached by Braid et al. (2014). Our examination of Mastigoteuthis pyrodes indicates that this species does not belong in Mastigoteuthis or in any of the other genera defined by Braid et al. (2014). "M." pyrodes presently remains in Mastigoteuthis by default. On superficial examination one could easily conclude that " $M$." pyrodes does, indeed, belong in Mastigoteuthis. In fin length, fin shape and tentacle structure "M." pyrodes is most similar to members of Mastigoteuthis. The most compelling feature for placing "M." pyrodes in Mastigoteuthis (and the feature that excludes this species from all other genera in the family) is the unique presence of readily visible integumental photophores on the mantle, head and ventral arms in these taxa. A closer comparison of the integument of "M." pyrodes and the type species of Mastigoteuthis, however, shows that they are very different.

The photophores of Mastigoteuthis agassizii Verrill, 1881, the type species of the genus, appear to lie in pockets (Fig. 1). The appearance of a pocket is due to the presence of transparent, vacuole-like cells that surround the photocytes and their covering chromatophores. A photophore of "M." pyrodes appears very different from that of M. agassizii under the dissecting microscope. It is seen as a slight bulge in the skin, 
not a pocket (i.e., without obvious vacuole-like cells), and is backed by a white reflector and covered by a dark chromatophore (Fig. 2B). Other features of the skin are also important. Mastigoteuthis agassizii has relatively few, scattered chromatophores in the epidermis and each is surrounded by a white ring (the thick edge of a disc that seems to extend beneath the chromatophore); this leaves most of the pigment of the skin in the dermis and not in chromatophore organs of the epidermis (Fig. 2A). In contrast, "M." pyrodes lacks these ringed chromatophores but has more numerous and densely arranged, typical chromatophores which provide most of the skin pigmentation, even though light pigmentation is present in the underlying dermis. Mastigoteuthis agassizii also has numerous small, spherical, white structures in the skin whose histology and function are unknown. These structures are lacking in "M." pyrodes.

These large differences in the structure of the integument, by themselves, are enough to conclude that "M." pyrodes is not a Mastigoteuthis. "M." pyrodes, however, also differs from species of Mastigoteuthis in the distribution of the photophores: both taxa have photophores on the ventral surfaces of the mantle, head and ventral arms, but only in "M." pyrodes are photophores also present on the ventral sides of the fins and the dorsal surfaces of the head and mantle. Moreover, the eyelid photophore in " $M$." pyrodes is much larger than its integumental photophores, while in Mastigoteuthis species the eyelid and integumental photophores are approximately the same size. One other major difference in these taxa is important in the derivation of the new generic name: the funnel component of the funnel/mantle locking apparatus. In "M." pyrodes this structure has a large tragus but is without an antitragus and without a posterior undercut shelf; these latter two features are always present in Mastigoteuthis species, although weakly expressed in some.

Because of these large morphological differences between "M." pyrodes and true species of Mastigoteuthis, we place "Mastigoteuthis" pyrodes as the sole species in a new genus, Mastigotragus.

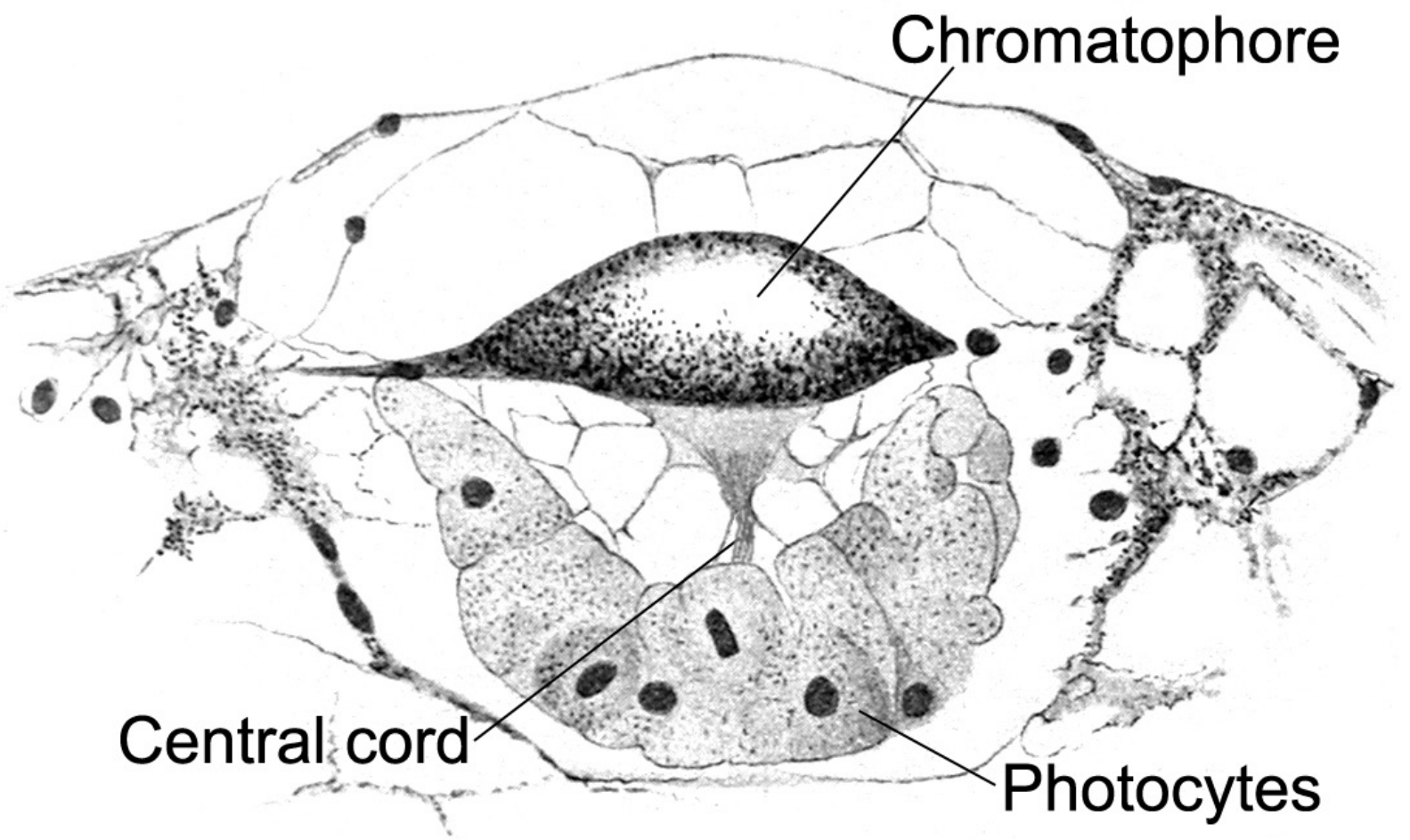

Fig. 1. Longitudinal section through an integumental photophore of Mastigoteuthis agassizii Verrill, 1881 (modified from Chun 1910). 

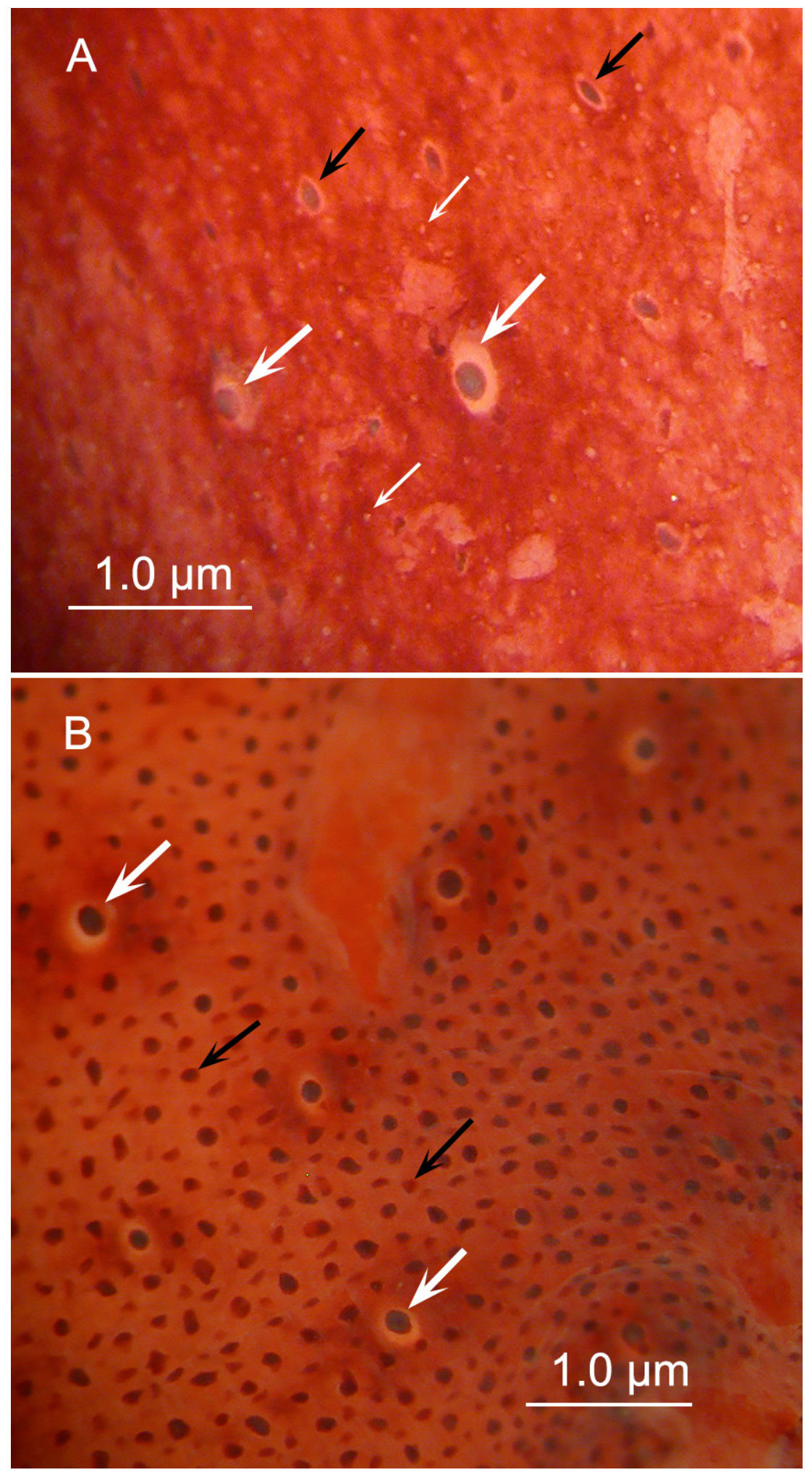

Fig. 2. Photomicrographs of the slightly damaged integument of the head (modified from Vecchione et al. 2004-2014). A. Mastigoteuthis agassizii. B. "Mastigoteuthis" pyrodes [= Mastigotragus pyrodes]. - Large, white arrows indicate photophores; only two photophores are visible in A but seven are visible in B. Small, white arrows indicate two of the many "white spherical structures." Black arrows indicate ringed chromatophores in A and typical chromatophores in B. 


\title{
Systematics
}

\author{
Class Cephalopoda Cuvier, 1795 \\ Subclass Coleoidea Bather, 1888 \\ Order Oegopsida d'Orbigny, 1845 \\ Family Mastigoteuthidae Verrill, 1881 \\ Mastigotragus gen. nov. \\ urn:1sid:zoobank.org:act:5F1DDC20-A391-4B52-BA8A-23FFC9F7888D
}

Type species: Mastigoteuthis pyrodes Young, 1972, by monotypy.

\section{Diagnosis}

A mastigoteuthid with (1) numerous small, but easily observed integumental photophores on the ventral surface of arms IV, on the dorsal and ventral surfaces of the head, mantle and fins, and with a relatively large photophore on each eyelid; (2) a broad funnel component of the funnel/mantle locking apparatus, with strong tragus, but without antitragus or undercut posterior margin; (3) comparatively large club suckers (about $0.3 \mathrm{~mm}$ in diameter).

\section{Etymology}

Here "mastigo" refers to the name of the family and "tragus" refers to the prominent tragus of the funnel locking apparatus. Mastigo is Latin for "whip" which refers to the form of the tentacle; "tragus" is a Latin word derived from the Greek trágos, indicating an appearance similar to the tragus of the human ear.

\section{Discussion}

No additional histological information is available on the structure of the integument of these taxa, but the position of Mastigotragus pyrodes as a separate genus is well supported by morphology. We hope that, before long, fresh specimens will be captured that will enable determination of the genetic relationships of this taxon within the family. The species is known only from the eastern North Pacific, mostly off Southern Calfornia. Additional information and illustrations of the diagnostic features of Mastigotragus pyrodes are presented on the species page of the Tree of Life website (Vecchione et al. 2004-2014).

\section{Acknowledgements}

We would like to thank Kat Bolstad and Paul McBride from the Auckland University of Technology for their help and the unknown reviewers for their helpful comments.

\section{References}

Braid H.E., McBride P.D. \& Bolstad K.S.R. 2014. Molecular phylogenetic analysis of the squid family Mastigoteuthidae (Mollusca, Cephalopoda) based on three mitochondrial genes. Hydrobiologia 725: 145-164. http://dx.doi.org/10.1007/s10750-013-1775-3

Chun C. 1910. Die Cephalopoden. Oegopsida. Wissenschaftliche Ergebnisse der Deutschen Tiefsee Expedition auf dem Dampfer ,Valdivia“ 1898-1899 18 (1): 1-401.

Salcedo-Vargas M.A. 1997. Cephalopods from the Netherlands Indian Ocean Programme (NIO) - II. Mastigoteuthid lineage and related forms. Beaufortia 47: 91-108. 
Salcedo-Vargas M.A. \& Okutani T. 1994. New classification of the squid family Mastigoteuthidae (Cephalopoda: Oegopsida). Venus 53: 119-127.

Vecchione M., Young R.E. \& Lindgren A. 2004-2014. Mastigoteuthidae Verrill, 1881. Mastigoteuthis Verrill, 1881. Whip-lash squid. The Tree of Life Web Project. Accessed 21 Jan. 2014 (under construction). http://tolweb.org/Mastigoteuthis/19453/2014.01.21

Young R.E. 1972. The systematics and areal distribution of pelagic cephalopods from the seas off Southern California. Smithsonian Contributions to Zoology 97: 1-159. http://dx.doi.org/10.5479/ $\underline{\text { si.00810282.97 }}$

Manuscript received: 9 July 2014

Manuscript accepted: 13 September 2014

Published on: 5 December 2014

Topic editor: Rudy Jocqué

Desk editor: Danny Eibye-Jacobsen

Printed versions of all papers are also deposited in the libraries of the institutes that are members of the EJT consortium: Muséum National d'Histoire Naturelle, Paris, France; National Botanic Garden of Belgium, Meise, Belgium; Royal Museum for Central Africa, Tervuren, Belgium; National History Museum, London, United Kingdom; Royal Belgian Institute of Natural Sciences, Brussels, Belgium; Natural History Museum of Denmark, Copenhagen, Denmark. 